\title{
SUICIDE IDEATION IN THE SOUTH AFRICAN POLICE SERVICES IN THE NORTH WEST PROVINCE
}

\author{
S ROTHMANN \\ G STRIJDOM \\ Programme in Industrial Psychology \\ PU for CHE, Potchefstroom
}

\begin{abstract}
The South African Police Service (SAPS) shows relatively high numbers of suicide. However, little is known about the suicide ideation of members within the SAPS. The objective of this research was to determine the relationship between sense of coherence, job satisfaction and suicide ideation among police personnel. The study population consisted of 120 police personnel in the North West Province. The results show that sense of coherence is related to suicide ideation in the case of white police members. Sense of coherence and satisfaction with independence, social status and supervision explained $55,30 \%$ of the variance in the suicide ideation scores of white police members.
\end{abstract}

\section{OPSOMMING}

'n Relatiewe hoë getal selfmoorde kom in die Suid-Afrikaanse Polisiediens (SAPD) voor. Min inligting oor die selfmoorddenkbeeldvorming van lede van die SAPD is egter bekend. Die doelstelling van hierdie navorsing was om te bepaal of daar ' $n$ verband bestaan tussen koherensiesin en werkstevredenheid enersyds en selfmoorddenkbeeldvorming by polisiepersoneel andersyds. Die ondersoekgroep het bestaan 120 lede van die SAPD in die Noordwes-Provinsie. Die resultate toon aan dat koherensiesin by wit polisiebeamptes verband hou met selfmoorddenkbeeldvorming. Koherensiesin en ontevredenheid met onafhanklikheid, sosiale status en toesighouding het $55,30 \%$ variansie in die selfmoorddenkbeeldvorming van wit polisiepersoneel verklaar.

There is a growing emphasis on identifying police members at risk of suicidal behaviour. This emphasis is attributable to the increasing incidence of suicide among police members worldwide, but also in the South African Police Service (SAPS). Suicide rates in 1994 were higher in the SAPS (60 out of 100 000) than in the general population of South Africa (5 out of 100 000) (Nel, 1994). Incidences of suicide in the SAPS increased from 65 in 1991 to 156 in 1997. In the North West Province 13 police members committed suicide in 1996 (Van Rensburg, 1998). However, there had been a small decline in suicides from 14 per 10000 police officials in 1996 to 11 per 10000 police officials in 1998 (Van Rensburg \& Van Rensburg, 2000).

Suicidal behaviour may be considered a domain of psychological disturbance and is associated with potentially severe mental and/or physical health outcomes. According to Reynolds (1991a) suicidal behaviour may be categorised as including suicide completion, overt intention, suicide attempt, and suicide ideation. Suicidal behaviour can be plotted on a continuum varying in severity from ideation, intent and attempt to completion. Suicide ideation therefore constitutes but one aspect of suicidal behaviour (Reynolds, 1991a). Research about suicide ideation may be viewed as an important and critical component in evaluating and promoting adult mental health. A strong association exists between suicide ideation and suicide (Jin \& Zhang, 1998).

Suicide ideation, which refers to the thoughts and cognitions about suicidal behaviour and intent, may be considered an early marker of more serious suicidal behaviour (Bonner \& Rich, 1987; Reynolds, 1991a; Shea, 1998). Suicide ideation can be characterised as ranging from relatively mild, general thoughts and wishes that one were dead to serious ideation about specific plans and means of taking one's life. Reynolds (1991a) defines suicide ideation as the domain of thoughts and ideas about death, suicide and serious self-injurious behaviour, and includes thoughts related to the planning, conduct and outcome of suicidal behaviour, particularly as the last relates to thoughts about the response of others.

The SAPS needs to intervene to decrease suicidal behaviour of police members. It is therefore necessary to study suicide ideation of police members and possible correlates thereof. Many factors may contribute to suicidal behaviour of police mem- bers, including the demands of the work situation (e.g. the high level of crime and dissatisfaction with aspects of the job) (Jacobs, 1998), factors outside the work situation (e.g. marital and financial problems) (Rossouw, 1998) and personal characteristics.

Previous research on suicide ideation focused on social factors (e.g. the effects of family, religion, interpersonal relations and social support) and individual factors (e.g. stress and depression) (Zhang \& Lin, 1998). The current research focuses on the possible relationship between sense of coherence (Antonovsky, 1987), job satisfaction (Weiss, Dawis, England \& Lofquist, 1967) and suicide ideation (Reynolds, 1991a).

The objective of this research was to determine the relationship between sense of coherence, job satisfaction and suicide ideation of police members in the North West Province.

Suicide ideation, sense of coherence and job satisfaction Suicide ideation as a psychological construct is more phenomenological than theoretical in nature (Reynolds, 1991a). Individuals measuring high on suicide ideation wish they had never been born, feel life is not worth living, wish they were dead, and think that others would realise their worth when they are dead. They have thoughts of killing themselves, as well as thoughts on specific methods they can use and times or places at which to kill themselves.

A number of researchers have focused on suicide ideation as an important aspect of suicidal behaviour. Schotte and Clum (1982) found a relationship between the frequency of suicide ideation and the likelihood of attempts at suicide. Bonner and Rich (1987) formulated a stress-vulnerability model of suicidal behaviour in college students in which suicide ideation represents a key variable in the development of more serious suicidal behaviour. Suicide ideation is consistent with a cognitivebehavioural focus and may be viewed as a domain of self-statements. Suicide ideation has been associated with depression and anxiety disorders (Zhang, 1996).

Lester (1987) as well as Lester and Francis (1993) investigated the relationship between suicide ideation and personality variables and indicated that neuroticism is strongly (positively) related to suicidal thinking in non-clinical samples. Jin and Zhang (1998) found that psychological well-being is a much stronger predictor of suicide ideation than physical well-being, especially when an individual suffers from depression. Velting (1999) found a positive correlation between neuroticism and suicide ideation, and a 
negative correlation with self-discipline. It could be expected that psychological well-being (and psychological strengths) (Strümpfer, 1995), which is healthy, positive, and pro-social, should be a buffer against suicide ideation, which is unhealthy, negative and asocial. One of these psychological strengths, which correlates inversely with neurotiscism (see Mlonzi \& Strümpfer, 1998), is sense of coherence.

Sense of coherence is a construct from a salutogenic paradigm (Antonovsky, 1987; Strümpfer, 1990) or fortigenic paradigm (Strümpfer, 1995). Sense of coherence can be described as the extent to which one has a pervasive, enduring though dynamic feeling of confidence that one's internal and external environments are predictable and that there is a high probability that things will work out as well as can be reasonably expected. It thus influences an individual's perception of stimuli. The definition of sense of coherence includes three dimensions that represent the concept, namely comprehensibility, manageability and meaningfulness (Antonovsky, 1987, 1991). Comprehensibility refers to the extent to which one perceives stimuli from the internal and external environment as information that is ordered, structured and consistent. Manageability refers to the extent to which individuals experience events in life as situations that are endurable or manageable and can even be seen as new challenges. Meaningfulness refers to the extent to which one feels that life is making sense on an emotional and not just a cognitive level.

Petrie and Brook (1992) found that a low sense of coherence is related to suicidal behaviour. Various studies also showed negative correlations between sense of coherence and negative affect (e.g. anxiety) (Carmel \& Bernstein, 1990; Flannery \& Flannery, 1990; Frenz, Carey \& Jorgenson, 1993; Gibson \& Cook, 1996; Kravetz, Drory \& Florian, 1993). Strümpfer (1995) found that sense of coherence correlated significantly with health, psychological health and low feelings of helplessness. It was found that sense of coherence significantly correlates with a measure of general health, psychological well-being and social support, but it correlated negatively with feelings of helplessness. Sense of coherence is also related to job satisfaction and life satisfaction (Rothmann, 2000; Strümpfer, Danana, Gouws \& Viviers, 1998). An individual with a strong sense of coherence will be more inclined to understand the nature and dimensions of an acute or chronic stressor and will define it as something that he or she can cope with. He or she will regard it as manageable by using resources within his or her own or others' control rather than becoming helpless. It is therefore hypothesised that a weak sense of coherence could be related to suicide ideation.

Few research studies were carried out concerning the relationship between the work environment and suicide ideation. Samuelson, Gustavsson, Petterson, Arnetz and Asberg (1997) studied the relationship between suicidal feelings, attempted suicide and aspects of the work environment and well being in Swedish nursing personnel. They found that a negative work environment was associated with burnout and depression, which in turn were related to suicide ideation. They found indirect evidence that a negative work environment may increase suicidal feelings. Goldney, Winefield, Tiggeman and Winefield (1995) found an association between dissatisfaction with employment and suicide ideation.

Police members work in circumstances of chronic stress (Maynard, Maynard, Mccubin \& Shao, 1980). Irregular working hours, poor working conditions, constant fear and trauma make police members more susceptible to suicide. Research by Hageman (1978) has shown that stressors in the work environment may be related to suicide ideation. Shift work, the dangers involved in police work, poor working conditions and low salaries seem to be related to job dissatisfaction, stress and suicidal tendencies (Kruger, 1996; Lott, 1995). According to McCafferty (1992), suicide of police members could largely be ascribed to stressors at work. Factors that may cause distress include authoritarian structure, lack of participation in decisionmaking, lack of administrative support, unfair discipline, unfair promotion and the nature of police work.
According to Violanti (1996) police members' experiences of organisational practices and the inherent nature of police work seem to be related to stress. Therefore it was decided to focus on satisfaction with job-related factors as a possible predictor of suicide ideation. Job satisfaction is an affective (emotional) reaction to a job which stems from the incumbent's comparison of actual outcomes with the required outcomes (Cranny, Smith \& Stone, 1992). Employees seek to achieve and maintain correspondence with their environment (Weiss, Dawis, England \& Lofquist, 1967). Correspondence with the environment can be described in terms of the individual fulfilling the requirements of the environment, and the environment fulfilling the requirements of the individual (Cook, Hepworth, Wall \& Warr, 1981). This means that employees would experience job satisfaction if they feel that their individual capacities, experience and values can be utilised in their work environment and that the work environment offers them opportunities and rewards.

Interpersonal relations in the work context may be related to suicide ideation. Interpersonal relations play a crucial role in determining an individual's well-being. Because good relations with people are associated with happiness, and because unhappiness (depression) predicts suicide ideation, a connection can be built between interpersonal relations and suicide ideation (Zhang \& Jin, 1998). Zautra, Burleson, Matt, Roth and Burrows (1994) found that positive interpersonal events were inversely related to depression, whereas conflictual interpersonal events correlated directly with higher levels of depression.

An important factor in the relationship between stress and depression is the amount of social support an individual has available when confronted with stressful events (Brown \& Harris, 1978). The more social support a person receives (in the work context or from the family and community), the less he or she experiences suicide ideation (Yang \& Clum; 1994, Zhang \& Jin, 1998). Zhang and Jin (1998) found that interpersonal conflict had the greatest and total effect on suicide ideation, and social isolation was the weakest predictor among three measures of interpersonal relations.

\section{RESEARCH METHOD}

\section{Research design}

A survey design was used to reach the research objective. The specific design is the cross-sectional design, whereby a sample is drawn from a population at one time (Shaughnessy \& Zechmeister, 1997). Information collected is used to describe the population at that time. This design can be used also to assess interrelationships among variables within a population. According to Shaughnessy and Zechmeister (1997) this design is ideally suited to the descriptive and predictive functions associated with correlational research.

\section{Sample}

A non-probability sample was taken from the six largest police stations in the Marico area of the North West Province. The sample consisted of constables $(n=6)$, sergeants $(n=77)$ and inspectors $(\mathrm{n}=37)$ and included 92 males and 28 females. Most participants (93\%) were between the ages of 26 and 45, married $(67 \%)$, had a qualification of Standard 10 or higher $(87 \%)$ and had between three and 15 years' $(85 \%)$ service in the SAPS.

\section{Measuring instruments}

Three questionnaires were used in the study, namely the Orientation to Life Questionnaire (OLQ) (Antonovsky, 1987), the Minnesota Job Satisfaction Index (Weiss et al., 1967), and the Adult Suicide Ideation Questionnaire (ASIQ) (Reynolds, 1991a).

The Orientation to Life Questionnaire (OLQ) was used to measure participants' sense of coherence. Antonovsky (1993) reported alpha coefficients of the OLQ in 29 research studies varying between 0,85 and 0,91 . Test-retest reliability studies found coefficients between 0,41 and 0,97 (Antonovsky, 1993). The alpha coefficient of the OLQ in this study was 0,89 , which may be regarded as acceptable (Nunnally \& Bernstein, 1994). 
Regarding the construct validity of the OLQ, it was found that there is a negative relationship between the OLQ and experienced stress and that the OLQ correlates negatively with the "State-Trait Anxiety Inventory-Trait" and the "Beck Depression Inventory” (Frenz et al., 1993).

The MinnesotaJob Satisfaction Index was used to measure participants' job satisfaction (Weiss et al., 1967). The latter researcher argues that the interaction between the work personality (individual needs and characteristics of the worker) and the work environment is responsible for satisfaction. The long form of the Minnesota Job Satisfaction Index, which consists of 100 items, was used in this study (Weiss et al., 1967). The questionnaire provides a valid and reliable measure specifically of general job satisfaction (Cook et al., 1981). The alpha coefficient of the general satisfaction score of the Minnesota Job Satisfaction Index in this study was 0,87 .

The Adult Suicide Ideation Questionnaire (ASIQ) (Reynolds, 1991a) was used to measure participants' current level of suicide ideation. Each of the items measures a specific suicidal behaviour or thought. The maximum possible score is 150 , with higher scores indicating more numerous and/or frequent suicidal thoughts. Reynolds (1991a) reported that the internal consistency (coefficient alpha) of the ASIQ is 0,96, while Osman et al. (1999) found a coefficient alpha of 0,98 . The test-retest reliability of the ASIQ varies between 0,86 and 0,95 (Reynolds, 1991b). Reynolds (1991a) provided evidence for the content, construct and criterion-related validity of the ASIQ. Osman et al. (1999) found that the ASIQ differentiated significantly between suicide attempt and psychiatric control groups.

\section{Statistical analysis}

The statistical analysis was carried out with the help of the SASprogram (SAS Institute, 1996). Because a non-probability sample was used in the present study, descriptive statistics were used. The Cronbach alpha coefficient was determined to indicate the internal consistency of the measuring instruments. Pearson's correlations were used to determine the relationship between variables. For the purposes of the present study, $r=0,30$ (medium effect) (Cohen, 1988) is regarded as practically significant.

A stepwise multiple regression analysis was conducted to determine the proportion of variance in the dependent variable (suicide ideation) that is explained by the independent variables (sense of coherence and job satisfaction). The effect size (which indicates practical significance) in the case of multiple regression is given by the following formula:

$f^{2}=\mathrm{R}^{2} / 1-\mathrm{R}^{2}$

For the purposes of this research $f^{2}=0,10$ (medium effect) is regarded as practically significant (Steyn, 1999).

\section{RESULTS}

The descriptive statistics of the MSQ, the OLQ and the ASIQ for the different race groups are reported in Table 1.

TABLE 1

DESCRIPTIVE STATISTICS OF THE CONSTRUCTS FOR DIFFERENT RACE GROUPS

\begin{tabular}{lrrrrrc}
\hline Item & \multicolumn{3}{c}{ White (n= 43) } & \multicolumn{3}{c}{ Black (n= 77) } \\
\hline & Mean & $S D$ & $\alpha$ & Mean & $S D$ & $\alpha$ \\
Job satisfaction: Total & 414,81 & 50,16 & 0,87 & 425,36 & 49,99 & 0,87 \\
Ability & 22,79 & 5,41 & 0,51 & 21,54 & 4,29 & 0,09 \\
Performance & 21,09 & 4,95 & 0,43 & 23,45 & 5,53 & 0,56 \\
Activity & 21,48 & 3,57 & 0,32 & 21,63 & 4,13 & 0,19 \\
Promotion & 18,88 & 6,17 & 0,59 & 20,67 & 4,47 & 0,25 \\
Authority & 23,65 & 3,90 & 0,14 & 23,01 & 4,75 & 0,39 \\
Company policy & 16,74 & 5,76 & 0,56 & 19,23 & 4,97 & 0,35 \\
Reward & 17,56 & 5,42 & 0,36 & 16,50 & 5,12 & 0,37 \\
Co-workers & 21,63 & 5,34 & 0,49 & 21,56 & 4,64 & 0,25 \\
Creativity & 22,44 & 4,68 & 0,37 & 21,31 & 5,17 & 0,42 \\
Independence & 23,51 & 5,40 & 0,59 & 22,32 & 4,82 & 0,29
\end{tabular}

\begin{tabular}{lrrrrrr}
\hline Item & \multicolumn{3}{c}{ White (n= 43) } & \multicolumn{3}{c}{ Black (n = 77) } \\
\hline & Mean & $S D$ & $\alpha$ & Mean & $S D$ & $\alpha$ \\
Moral values & 21,06 & 4,93 & 0,38 & 22,32 & 4,59 & 0,17 \\
Recognition & 18,95 & 5,77 & 0,60 & 20,84 & 5,91 & 0,55 \\
Security & 20,07 & 5,29 & 0,48 & 21,16 & 5,33 & 0,38 \\
Social service & 21,63 & 4,87 & 0,42 & 20,83 & 4,38 & 0,15 \\
Social status & 21,65 & 4,64 & 0,32 & 22,54 & 4,66 & 0,23 \\
Supervision human & 17,93 & 5,50 & 0,47 & 19,74 & 4,41 & 0,08 \\
Supervision technical & 19,35 & 5,29 & 0,47 & 20,41 & 4,06 & 0,10 \\
Responsibility & 23,16 & 5,56 & 0,69 & 24,21 & 6,02 & 0,65 \\
Variety & 21,60 & 4,45 & 0,27 & 21,96 & 4,25 & 0,15 \\
Work conditions & 19,60 & 6,22 & 0,64 & 20,06 & 4,41 & 0,16 \\
SOC (Total) & 122,61 & 18,56 & 0,77 & 127,75 & 17,14 & 0,67 \\
ASIQ (Total) & 13,51 & 25,30 & 0,98 & 16,52 & 25,71 & 0,95 \\
\hline
\end{tabular}

Table 2 shows that the mean of the ASIQ for whites was 13,51, while the mean for blacks was 16,51. Table 2 shows that the mean of Total Job Satisfaction for black police personnel is 425,36 , while the mean for white police personnel is 414,81 .

The Cronbach coefficient alpha of the MSQ is 0,87 for whites as well as for blacks, although the coefficient alphas of the subscales for Blacks are questionable. The Cronbach coefficient alphas of the OLQ are 0,77 for whites and 0,67 for blacks, while the internal consistencies of the ASIQ are 0,98 and 0,95 for whites and blacks respectively. These internal consistencies could be regarded as acceptable (Nunnally \& Bernstein, 1994).

The product-moment correlations between the OLQ, the MSQ and the ASIQ are reported in Table 2.

TABLE 2

PRODUCT MOMENT CORRELATIONS BETWEEN SUICIDE IDEATION, SENSE OF COHERENCE AND JOB SATISFACTION

\begin{tabular}{lrrrrrr}
\hline Item & \multicolumn{3}{c}{ MSQ } & & \multicolumn{3}{c}{ ASIQ } \\
\hline & White & Black & Total & White & Black & Total \\
OLQ & $0,31 \star$ & 0,23 & 0,28 & $-0,51 \star \star$ & 0,24 & $-0,33 \star$ \\
MSQ - Total & - & - & - & $-0,29$ & $-0,24$ & 0,20 \\
\hline
\end{tabular}

$\star$ Correlation is practically significant $\mathrm{r}=0,30$ (medium effect)

$\star \star$ Correlation is practically significant $r=0,50$ (large effect)

Table 2 shows that a practically significant correlation of large effect $(r=-0,51)$ exists between suicide ideation and sense of coherence in the sample of white police personnel, while a practical significant correlation of medium effect $(r=-0,33)$ exists in the total sample. No practically significant correlations were found between sense of coherence and job satisfaction or suicide ideation and job satisfaction for the total sample. A practically significant correlation of medium effect $(r=0,31)$ was found between the job satisfaction and sense of coherence of white police personnel.

Next, a stepwise regression analysis was done on the results of the white group. A significance level of $p<0,15$ was set. The variables included in the regression analysis for white police personnel are reported in Table 3.

TABLE 3

REGRESSION ANALYSIS OF SENSE OF COHERENCE, JOB SATISFACTION AND SUICIDE IDEATION IN THE WHITE GROUP

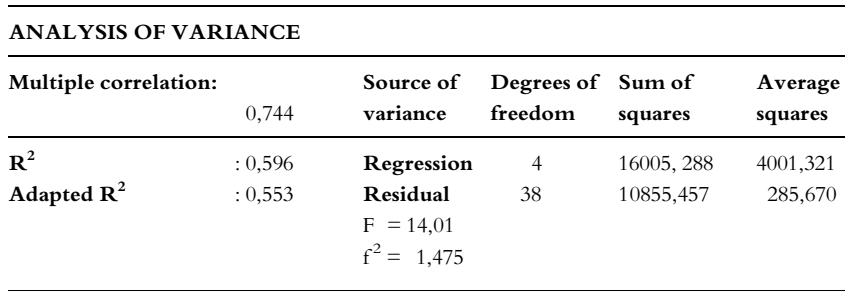




\begin{tabular}{lrccl}
\hline $\begin{array}{l}\text { VARIABLES } \\
\text { Independent } \\
\text { variables }\end{array}$ & B & $\begin{array}{l}\text { Standard error } \\
\text { of B }\end{array}$ & f value & $\mathbf{p}$ \\
\hline Constant & 114,00 & 20,766 & 30,14 & 0,0001 \\
SOC & $-0,664$ & 0,150 & 19,67 & 0,0001 \\
Independence & 1,936 & 0,527 & 13,51 & 0,0007 \\
Social status & $-1,398$ & 0,607 & 5,30 & 0,0269 \\
Supervision Human & $-1,913$ & 0,481 & 15,80 & 0,0003 \\
\hline
\end{tabular}

An inspection of Table 3 shows that a total of $55,30 \%$ of the variance in suicide ideation of white police personnel (as measured by the ASIQ) is predicted by a combination of four variables, namely sense of coherence and satisfaction with independence, social status and supervision (human). The resulting multiple correlation of 0,77 is practically significant (large effect) $\left(f^{2}=1,475\right)$.

Because of the low Cronbach coefficient alphas of the scales of the measuring instruments for black police personnel, the regression analysis was not carried out for them.

\section{DISCUSSION}

The mean of the ASIQ for whites was 13,51, while the mean for blacks was 16,51 . Compared with the mean of 8 that was found for adults and 11 for students, it seems that the scores of white and black police members are higher. The average scores of both whites and blacks are well below the cut-off point of 31, which is regarded as severe suicide ideation (Reynolds, 1991a). Reynolds (1991a) designated six items of the ASIQ on the basis of their significant potency for more serious selfdestructive behaviour (regardless of scores). Based on their responses to these six items, 12 police members in this study could be regarded as at risk in terms of suicidal behaviour.

The results show that black police personnel obtained higher mean scores on suicide ideation and sense of coherence than white police personnel. Suicide ideation of the total sample of police personnel is related to their sense of coherence. This result confirms the findings of Petrie en Brook (1992). Suicide ideation of white police personnel is related to a low sense of coherence and dissatisfaction with company policy, supervision and working conditions.

The means of the OLQ for the white and black police personnel are 122,61 and 127,75 respectively, which is substantially lower than means obtained in other samples (Rothmann, 2000). Police personnel in this study were especially dissatisfied with the rewards, company policies, supervision (especially that related to human aspects) and physical working conditions (which can be described as uncomfortable and even dangerous). They experienced a higher degree of job satisfaction regarding responsibility (to use own discretion), authority (to tell others what to do) and independence (the opportunity to work independently). White police personnel are relatively dissatisfied with supervision (human and technical aspects), rewards (salaries and fringe benefits), company policy, working conditions, recognition and promotion. Black police personnel are more dissatisfied with company policy, rewards and supervision (human aspects).

The job satisfaction of police personnel is related to their sense of coherence. This finding confirms the findings of McCafferty (1992) and Violante (1995). White police personnel who have a high sense of coherence are also more satisfied with their work (which confirms the findings of Rothmann, 2000 and Strümpfer et al., 1998) and less inclined to suicide ideation.

A low sense of coherence, satisfaction with independence and dissatisfaction with social status and supervision (human) explain $55,30 \%$ of the variance in the suicide ideation scores of white police members. White police personnel with a low sense of coherence who are satisfied with their independence (probably because they prefer to isolate themselves from others' support) and who are dissatisfied with their social status as well as their supervisors, obtained higher scores on suicide ideation. Satisfaction with the human aspects of supervision (including the understanding between the police member and his or her supervisor, the way he or she is treated by the supervisor and the way his or her grievances are handled) predicts suicide ideation of police members. White police members' dissatisfaction with their social position in and the regard of the community are related to suicide ideation, which may be related to a low self-regard.

In interpreting these results it should be remembered that the sample consisted only of police members in the Marico area of the North West Province. The results could not be generalised to other areas and provinces. Another shortcoming of the research was that the causality of the relationships between the various constructs could not be determined.

\section{RECOMMENDATIONS}

The SAPS should attend to the suicide ideation of police personnel and correlates thereof, such as dissatisfaction with social status and supervision. The sense of coherence of police members should be assessed and developed in order to decrease suicide ideation. The SAPS can select individuals who have a strong sense of coherence, depending on the job. However, more research is needed, especially because the relationship between sense of coherence and suicide ideation were not studied in a selection context.

By equipping police personnel with the necessary knowledge, skills, material, instruments and other resources, and by ensuring a balance in the load of tasks to be handled, they will increasingly feel that the work expectations are manageable and within their or important other's power. Senior police personnel should be treated in identifying individuals who tend towards suicide ideation. They should also be sensitised to the effect of their behaviour on members who have ideas about suicide. Support groups for uniformed police personnel should be used and lay counsellors should be trained to provide social support to individuals who are stressed.

Participation in decision-making will enhance the police members' feeling of membership and contribute to the meaningfulness component of sense of coherence. Police personnel should have the freedom to disagree with their supervisors and to discuss what to do with them (rather than to be told what to do). The role of station commanders is crucial in this regard.

Research should be undertaken into other factors in the work environment that could be related to suicide ideation of white and black police personnel. The role of social and interpersonal factors in suicide ideation should also be researched. It seems that the development of management and interpersonal skills of managerial personnel in the SAPS could contribute to positive affect and less suicide ideation.

\section{REFERENCES}

Antonovsky, A. (1987). Unraveling the mystery of health: How people manage stress and stay well. San Francisco, CA: JosseyBass.

Antonovsky, A. (1993). The structure and properties of the Sense of Coherence Scale. Social Science and Medicine, 36, $725-733$.

Bonner, R.L., \& Rich, A.R. (1987). Toward a predictive model of suicide ideation and behavior: Some preliminary data in college students. Suicide and Life-Threatening Behavior, 17, 50-63.

Brown, G. \& Harris, T. (1978). Social origins of depression: A study of psychiatric disorders in women. New York: Free Press.

Cantor, C. H., Tyman, R. \& Slater, P.J. (1995). A historical survey of police suicide in Queensland, Australia, 1843-1992. Suicide and Life-threatening Behavior, 25, 499-507.

Carmel, S. \& Bernstein, J. (1990). Trait anxiety, sense of coherence and medical school stressors: Observations at three stages. Anxiety Research, 3(1), 51-60. 
Cohen, J. (1988). Statistical power analysis for the behavioral sciences. Revised ed. Orlando: Academic Press.

Cook, J.D., Hepworth, S.J., Wall, T.D. \& Warr, P.B. (1981). The experience of work: A Compendium and review of 249 measures and their use. London: Academic Press.

Cranny, C.J., Smith, P.C. \& Stone, E.F. (1992). Job satisfaction: How people feel about their jobs and how it affects their performances. New York: Lexington Books.

Flannery, R.B., \& Flannery, G.J. (1990). Sense of coherence, life stress, and psychological distress: A prospective methodological enquiry. Journal of Clinical Psychology, 46, 415-420.

Frenz, A.W., Carey, M.P., \& Jorgensen, R.S. (1993). Psychometric evaluation of Antonovsky's sense of coherence scale. Psychological Assessment, 5, 145-153.

Gibson, L.M. \& Cook, M.J. (1996). Neuroticism end sense of coherence. Psychological Reports, 79, 343-349.

Goldney, R.D., Winefield, A.H., Tigemann, M. \& Winefield, H.R. (1995). Suicide ideation and unemployment: A prospective longitudinal study. Archives of Suicide Research, 1(3), 175-184.

Hageman, M.J.C. (1978). Occupational stress and marital relationships. Journal of Police Science and Administration, 6, 402411.

Jacobs, Q. (1998, August). Selfmoord in die SAPD: Die laaste uitweg, of is dit! Union Post, 3, 4.

Jin, S. \& Zhang, J. (1998). The effects of physical and psychological well-being on suicide ideation. Journal of Clinical Psychology, 54, 401-413.

Kravetz, S., Drory, Y. \& Florian, V. (1993). Hardiness and sense of coherence and their relation to negative affect. European Journal of Personality, 7, 233-244.

Kruger, G. (1996, January 30). SAPD-stres:'n Kultuur teen sielkunde kwel: Geestesesondheid moet prioriteit wees. Beeld, p. 11

Lester, D. (1987). Suicidal preoccupation and dysthymia in college students. Psychological Reports, 61, 762.

Lester, D. \& Francis, L.J. (1993). Is religiosity related to suicide ideation after personality and mood are taken into account? Personality and Individual Differences, 15, 591-592.

Lott, L.D. (1995, November). Deadly secrets: Violence in the police family. FBI Law Enforcement Bulletin, 64, 12-16.

Maynard, P., Maynard, N., Mccubin, H. I. \& Shao, D. (1980). Family life and the police profession: coping patterns wives employ in managing job stress and the family environment. Family Relations, 29, 495-501.

McCafferty, F.L. (1992). Stress and suicide in police officers: Paradigm of occupational stress. Southern Medical Journal, 85, 233-243.

Mlonzi, E.N. \& Strümpfer, D.J.W. (1998). Antonovsky's sense of coherence scale and $16 \mathrm{PF}$ second-order factors. Social Behaviour and Personality, 26(1), 39-50.

Moore, D.S. (1995). The basic practice of statistics. New York: W.H. Freeman.

Nel, J. (1994). A contextual approach to post-shooting trauma in the South African Police Service. Unpublished master's dissertation, Rand Afrikaans University, Johannesburg.

Nunnally, J.C., \& Bernstein, I.H. (1994). Psychometric theory (3rd ed.). New York: McGraw-Hill

Osman, A., Kopper, B.A., Linehan, M.M., Barrios, F.X., Gutierrez, P.M. \& Bagge, C.L. (1999). Validation of the Suicide ideation Questionnaire and the Response for Living Inventory in an adult psychiatric inpatient sample. Psychological Assessment, 11, 115-123.

Petrie, K. \& Brook, R. (1992). Sense of coherence, self-esteem, depression and hopelessness as correlates of reattempting suicide. British Journal of Clinical Psycholog $\gamma, 31,293-300$.
Pieterse, J.J. (1993).'n Psigologiese outopsie van polisieselfmoord. Ongepubliseerde meestersgraadskripsie, Universiteit van Suid-Afrika, Pretoria.

Reynolds, W. M. (1991). Suicide ideation Questionnaire: Professional Manual. Odessa, FL: Psychological Assessment Resources.

Reynolds, W.M. (1991b). Psychometric characteristics of the Adult Suicide ideation Questionnaire with college students. Journal of Personality Assessment, 56, 289-307.

Rossouw, L. (1998). Selfmoord in die SAPD: Navorsingsbevindinge -1994-1997. Pretoria: Sielkundige dienste.

Rothmann, S. (2000, July). Sense of coherence, locus of control and job satisfaction. Paper presented at the 28th International Congress of Psychology, Stockholm, Sweden.

Samuelson, M., Gustavsson, J.P., Petterson, I.L., Arnetz, B. \& Asberg, M. (1997). Suicidal feelings and work environment in psychiatric nursing personnel. Social Psychiatry and Psychiatric Epidemiology, 32, 391-397.

SAS Institute. (1996). SAS users guide: Basics. Version 6th ed. Cary, NC: SAS Institute Inc.

Schotte, D.E., \& Clum, G.A. (1982). Suicide ideation in a college population: A test of a model. Journal of Consulting and Clinical Psychology, 50, 690-696.

Shaughnessy, J.J. \& Zechmeister, E.B.(1997). Research methods in psychology (4th ed.). New York: McGraw-Hill.

Shea, S.C. (1998). The chronological assessment of suicide events: A practical interviewing strategy for the elicitation of suicide ideation. Journal of Clinical Psychiatry, 59, 58-72.

Steyn, H.S. (1999). Praktiese betekenisvolheid: Die gebruik van effekgroottes. Wetenskaplike bydraes Reeks B: Natuurwetenskappe Nr. 117. Potchefstroom: PU vir $\mathrm{CHO}$.

Strümpfer, D.J.W. (1990). Salutogenesis: A new paradigm. South African Journal of Psychology, 20, 265-276.

Strümpfer, D.J.W. (1995). The origins of health and strength: From salutogenesis to fortigenesis. South African Journal of Psychology, 25, 81-89.

Strümpfer, D.J.W., Danana, N., Gouws, J.F. \& Viviers, M.R. (1998). Personality dispositions and job satisfaction. South African Journal of Psychology, 28, 92-99.

Van Rensburg, P.J. (1998, February). An analysis of the suicide statistics of the SAPS: Northwest Province. Paper presented at the SAPS congress, Johannesburg.

Velting, D.M. (1999). Suicide ideation and the five-factor model of personality. Personality and Individual Differences, 27, 943-952.

Violanti, J.M. (1995, February). The mystery within: Understanding police suicide. FBI Law Enforcements Bulletin, 64, 19-23.

Violanti, J.M. (1996). Police suicide: Epidemic in blue. Springfield, IL: S.C.Thomas.

Weiss, D.J., Dawis, R.V., England, G.W. \& Lofquist, L.H. (1967). Manual for the Minnesota Satisfaction Questionnaire. Minneapolis, MN: University of Minnesota.

Yang, B. \& Clum, G.A. (1994). Life stress, social support, and problem-solving skills predictive of depressive symptoms, hopelessness and suicide ideation in an Asian student population: A test of a model. Suicide and Life-Threatening Behaviour, 24, 127-139.

Zautra, A., Burleson, M.H., Matt, K., Roth, S. \& Burrows, L. (1994). Interpersonal stress depression, and disease activity in rheumatoid arthritis and osteoarthritis patients. Health Psychology, 13, 139-148.

Zhang, J. (1996). Suicides in Beijing, China, 1992-1993. Suicide and Life-Threatening Behaviour, 26, 175-180.

Zhang, J. \& Jin, S. (1998). Interpersonal relations and suicide ideation in China. Genetic, Social and General Psychology Monographs, 124, 79-94. 